\title{
A molecular mimic demonstrates that phosphorylated human prolactin is a potent anti-angiogenic hormone
}

\author{
Eric Ueda',2, Ugur Ozerdem ${ }^{3}$, Yen-Hao Chen ${ }^{1}$, Min Yao ${ }^{4}$, Kuang Tzu Huang ${ }^{1}$, \\ Huiqin Sun ${ }^{3}$, Manuela Martins-Green ${ }^{4}$, Paolo Bartolini ${ }^{2}$ and Ameae M Walker ${ }^{4}$
}

\author{
1Division of Biomedical Sciences, University of California, Riverside, California 92521, USA \\ ${ }^{2}$ IPEN-CNEN-Biotechnology Department, Universidade de Sao Paulo, Sao Paulo, CEP 05508-900 Brazil \\ ${ }^{3}$ La Jolla Institute for Molecular Medicine, San Diego, California 92121, USA \\ ${ }^{4}$ Cell Biology and Neuroscience, University of California, Riverside, California 92521, USA
}

(Requests for offprints should be addressed to A M Walker; Email: ameae.walker@ucr.edu)

\begin{abstract}
S179D prolactin (PRL) is an experimentally useful mimic of naturally phosphorylated human prolactin. S179D PRL, but not unmodified PRL, was found to be anti-angiogenic in both the chorioallantoic membrane and corneal assays. Further investigation using human endothelial in vitro models showed reduced cell number, reduced tubule formation in Matrigel, and reduced migration and invasion, as a function of treatment with S179D PRL. Analysis of growth factors in human endothelial cells in response to S179D PRL showed: a decreased expression or release of endogenous PRL, heme-oxygenase-1, basic fibroblast growth factor (bFGF), angiogenin, epidermal growth factor and vascular endothelial growth factor; and an increased expression of inhibitors of matrix metalloproteases. S179D PRL also blocked signaling from bFGF in these cells. We conclude that this molecular mimic of a pituitary hormone is a potent anti-angiogenic protein, partly as a result of its ability to reduce utilization of several well-established endothelial autocrine growth loops, partly by its ability to block signaling from bFGF and partly because of its ability to decrease endothelial migration. These findings suggest that circulating levels of phosphorylated PRL may influence the progression of cancer and, furthermore, that S179D PRL may be a useful anti-angiogenic therapeutic.
\end{abstract}

Endocrine-Related Cancer (2006) 13 95-111

\section{Introduction}

Many tissues express prolactin (PRL) receptors (Costlow \& McGuire 1977, Meister et al. 1992, Royster et al. 1995), indicating the likelihood of a response to PRL, the primary source of which is the pituitary. In addition, a substantial proportion of these tissues express PRL (reviewed in Ben-Jonathan et al. 1996) and for some, such as the mammary gland and prostate, PRL functions as an autocrine growth factor (Ben-Jonathan et al. 1996, Clevenger \& Plank 1997, Schroeder et al. 2003). An autocrine PRL growth loop is present in cells representative of both steroiddependent and -independent breast and prostate cancer (Clevenger \& Plank 1997; reviewed in Ben-Jonathan et al. 2002), and is a potential target for therapeutics.
Since agents that regulate pituitary PRL synthesis and release are ineffective in extrapituitary tissues (BenJonathan et al. 1996), several laboratories have developed PRL receptor antagonists (Fuh \& Wells 1995, Lochan et al. 1995, Chen et al. 1998, 2002, Llovera et al. 2000, Xu et al. 2001, Beck et al. 2003). S179D PRL, a mimic of phosphorylated human PRL (Wang et al. 1996, Chen et al. 1998, Tuazon et al. 2002), was originally developed as a PRL receptor antagonist since we had shown that naturally phosphorylated PRL had this activity (Krown et al. 1992, Wang \& Walker 1993). It was anticipated therefore that S179D PRL would impair the growth of tissues utilizing PRL as a growth factor by blocking the effects of both pituitary and autocrine PRL. Indeed, this molecule has been shown to impair the development of a number of fetal tissues (Coss et al. 
2000, Yang et al. 2001, 2002), to inhibit the growth of mammary glands during pregnancy (Kuo et al. 2002, Naylor et al. 2005), to inhibit proliferation of human breast cancer cells in response to unmodified PRL (U-PRL) in vitro (Schroeder et al. 2003) and to inhibit the growth of human prostate cancer cells both in vitro and when grown as tumors in nude mice (Xu et al. 2001).

Further analysis of the effects of S179D PRL, however, made two points clear: first, that S179D PRL was not a pure antagonist (Bernichtein et al. 2001, Wu et al. 2003, Xu et al. 2003, Tan et al. 2005); and second, that it was more effective in vivo than in vitro (best illustrated in $\mathrm{Xu}$ et al. 2001). With regard to the first issue, we have demonstrated that in addition to its growth-inhibiting properties, S179D PRL promotes the expression of tissue-specific genes in both the mammary gland (Kuo et al. 2002, Wu et al. 2003) and the prostate (Xu et al. 2003). These dual antagonist/agonist activities are brought about by the inhibition of signaling to cell proliferation (Coss et al. 1999, Schroeder et al. 2003, Wu et al. 2003) and by production of alternative signals which result in the expression of tissue-specific genes (Wu et al. 2003) and cell cycle regulatory proteins (Wu et al. 2005). With regard to the greater efficacy in vivo (Coss et al. 2000, Xu et al. 2001, Kuo et al. 2002, Naylor et al. 2005), one potential explanation is that S179D PRL acts on a variety of cells and not just the mammary and prostate epithelial cells initially studied. Among these potential targets, cells of the developing vasculature are good candidates.

In addition to being a requirement for normal development, angiogenesis is also an essential element of many pathological processes, including tumor growth and metastasis, diabetic retinopathy and neurofibromatosis type 1 (reviewed in Folkman 1995, Ozerdem 2005). The development of anti-angiogenic therapies for treatment of these pathologies has therefore become an increasingly important goal of biomedical research. Endothelial cells have been shown to express PRL receptors (Corbacho et al. 2000, Merkle et al. 2000) as well as a unique receptor that binds a cleaved form of PRL (Clapp \& Weiner 1992). We therefore undertook the current study to determine whether part of the in vivo anti-growth efficacy of S179D PRL was the result of anti-angiogenic activity.

\section{Materials and methods \\ Recombinant prolactins}

Recombinant U-PRL and S179D PRL were produced as previously described (Chen et al. 1998). Endotoxin levels in the preparations were detected and measured with the Limulus amoebocyte lysate assay (E-Toxate kit; Sigma).

\section{Angiogenesis assays in the chicken chorioallantoic membrane (CAM)}

These assays were carried out using a modification of the method previously described (Martins-Green \& Kelly 1998). Briefly, $2 \mathrm{ml}$ albumin were withdrawn from 4-day fertilized eggs to drop the CAM away from the shell. Windows in the shell were made $3 \mathrm{~h}$ later and the eggs were incubated until day 9. Pellets were prepared by mixing $1 \mu \mathrm{g}$ U-PRL or S179D PRL, or $500 \mathrm{ng}$ basic fibroblast growth factor (bFGF), with $1 \%$ methylcellulose $(1: 1)$ in a total volume of $40 \mu \mathrm{l}$ per pellet. Then, $40 \mu \mathrm{l}$ drops were placed on parafilm and allowed to dry in a sterile hood for $2 \mathrm{~h}$. This procedure yielded small disc-shaped pellets, $5 \mathrm{~mm}$ in diameter and $0.1 \mathrm{~mm}$ thick. These were then placed between two large blood vessels of the 9-day-old CAMs; 5 days later, the pellets and the surrounding areas were removed, fixed and the CAMs examined for the degree of angiogenesis. Angiogenesis was quantified by estimation of the avascular area. Briefly, using enlarged photographs of the pellet circles, the areas that did not contain the normal frequency of smaller vessels present in the positive controls were cut out and weighed. Weights were converted to area knowing the magnification of the images. The positive controls with normal spacing of the small vessels were considered to have no avascular area. Negative controls consisted of pellets with water and methylcellulose only, and pellets containing both S179D PRL and a 3-fold excess of rabbit anti-human PRL (provided by A Parlow, Harbor General, Torrance, CA, USA). The bFGF pellet served as a positive control. The experiment was carried out five times with ten replicates for each treatment.

\section{Corneal angiogenesis assay}

The surgical procedure for inducing corneal angiogenesis in the mouse (Kenyon et al. 1996) was modified to incorporate two pellets in the corneal pocket instead of just a single pellet (Ozerdem \& Stallcup 2004). Slow-release polyhydroxyethyl methacrylate (hydron) (Hydro Med Sciences, Cranbury, NJ, USA) pellets $(0.4 \times 0.4 \times 0.2 \mathrm{~mm})$ were formulated to contain $45 \mu \mathrm{g}$ sucrose aluminum sulfate (sucralfate) (Sigma) plus one of three experimental additives: $90 \mathrm{ng}$ recombinant bFGF (Life Technologies, Carlsbad, CA, USA), 52.5 ng S179D PRL or $52.5 \mathrm{ng}$ U-PRL. Ten mice (6 weeks old; C57BL/6) were anesthetized 
with Avertin (0.015-0.017 ml/g body weight) and two pellets were implanted into the corneal stroma at a distance of $0.7 \mathrm{~mm}$ from the corneo-scleral limbus. Ten eyes received pairs of pellets containing bFGF and S179D PRL. Fellow eyes of each mouse received pairs of pellets containing bFGF and U-PRL. Over an 8-day period after surgery, the mice were examined to evaluate the progress of corneal angiogenesis in the operated eyes. On day 8, angiogenesis was quantified by determining the area of vascularization, as described previously (Kenyon et al. 1996, 1997).

\section{Cell culture}

Primary human umbilical vein endothelial cells (HUVEc) and primary human microvascular endothelial cells (HMVEc) were obtained from Clonetics (San Diego, CA, USA). The cells were usually used up to passage 5, but some repeat experiments used cells up to passage 10. HUVEc were grown on collagencoated plates in medium M199 supplemented with $10 \mathrm{mM}$ Hepes, $2.5 \mu \mathrm{g} / \mathrm{ml}$ thymidine, 140 USP units $/ \mathrm{ml}$ heparin, $5 \mathrm{ng} / \mathrm{ml}$ human bFGF (Sigma), 20\% fetal bovine serum (FBS; Gibco) as recommended by the supplier. HMVEc were grown on collagen-coated plates in endothelial growth medium with growth factors (EGM-2MV medium) (Clonetics).

\section{Cell proliferation assay}

HUVEc were seeded in 24-well plates at a density of $3 \times 10^{4}$ cells $/$ well in $1 \mathrm{ml}$ growth medium. After $24 \mathrm{~h}$, cells were incubated with either U-PRL or S179D PRL in human endothelial serum-free medium containing bFGF, as before, and epidermal growth factor (EGF) at $10 \mathrm{ng} / \mathrm{ml}$ (Sigma) (SFM). Cells were further incubated for $72 \mathrm{~h}$ at $37^{\circ} \mathrm{C}$. Cell number was determined using a colorimetric assay (Cell Titer; Promega) with the stringent modifications described previously (Huang et al. 2004).

\section{Endothelial tubule formation}

Matrigel with reduced growth factors (BD Biosciences, Palo Alto, CA, USA), diluted $1: 1$ with SFM was added $(350 \mu \mathrm{l})$ to each well of a 24 -well plate and allowed to polymerize fully at $37^{\circ} \mathrm{C}$ for $30 \mathrm{~min}$. A suspension of $3 \times 10^{4} \mathrm{HUVEc} /$ well in $400 \mu \mathrm{LFM}$ with reduced bFGF $(2.5 \mathrm{ng} / \mathrm{ml})$ supplemented with $5 \%$ FBS was transferred to each well. The cells were then treated with $1 \mu \mathrm{g} / \mathrm{ml}$ of either of the two forms of PRL. Cells were incubated for $24 \mathrm{~h}$ at $37^{\circ} \mathrm{C}$ in a humidified $5 \% \mathrm{CO}_{2}$ incubator and the tubule-like structures were observed and quantified in six random microscopic fields towards the center of the well (at $\times 20$ magnification).

\section{DNA content analysis}

HUVEc were cultured for 3 days in SFM with reduced bFGF $(2.5 \mathrm{ng} / \mathrm{ml})$ containing $5 \%$ FBS and either UPRL or S179D PRL $(1 \mu \mathrm{g} / \mathrm{ml})$. Cells were harvested by trypsinization, washed with cold Dulbecco's PBS (DPBS) and fixed with $75 \%$ ethanol in DPBS at $4{ }^{\circ} \mathrm{C}$ for $30 \mathrm{~min}$. Cell pellets were resuspended in $0.1 \%$ Triton X-100 (Sigma) in DPBS containing $200 \mu \mathrm{g} / \mathrm{ml}$ RNase (Sigma) and $10 \mu \mathrm{g} / \mathrm{ml}$ propidium iodide (Sigma), and incubated at room temperature for $30 \mathrm{~min}$. The fluorescence of individual cells was measured with a FACScan cytofluorometer equipped with CellQuest software (Becton Dickinson, Franklin Lakes, NJ, USA).

\section{Western blotting and immunoprecipitation}

To detect PRL receptor (PRLR) isoforms, equal quantities of lysate (1 $\mathrm{mg}$ protein) from treated and untreated HUVEc were immunoprecipitated with $1 \mu \mathrm{g}$ mouse anti-PRLR which recognizes the receptor extracellular domain (Zymed, San Francisco, CA, USA; catalog number, 35-9200); the immunocomplexes were captured with $100 \mu$ protein A-agarose bead slurry (Upstate Biotechnology, Inc., Lake Placid, NY, USA) and thoroughly washed. The beads were then resuspended in $50 \mu \mathrm{l}$ SDS-loading buffer and, after boiling for $5 \mathrm{~min}, 20 \mu \mathrm{l}$ of the supernatant were subjected to SDS-PAGE and subsequent transfer to a polyvinylidene fluoride (PVDF) membrane. AntiPRLR was used at $1: 1000$ dilution. Antigen-antibody interactions were detected using horseradish peroxidase-coupled secondary antibodies and enhanced chemiluminescence (ECL; Amersham). To detect activation of extracellular-regulated kinase (ERK) 1 and 2, cells were cultured in the absence of bFGF for $16 \mathrm{~h}$ and then treated with bFGF $(25 \mathrm{ng} / \mathrm{ml})$ or $b F G F$ and S179D PRL $(1 \mu \mathrm{g} / \mathrm{ml})$ for the times indicated. Cell lysate proteins were resolved on the gel and antiphosphoERK was used for Western blots (dilution 1:1000; Santa Cruz Biotechnology, Inc. Santa Cruz, CA, USA). The blots were stripped and re-probed with anti-total ERK (dilution 1:1000; Santa Cruz Biotechnology) to control for loading.

\section{Cloning ring migration assay}

A cloning ring, used to create a defined initial area of cells, was placed in the middle of a $35 \mathrm{~mm}$ Petri dish and a suspension of $10^{4} \mathrm{HMVEc}$ in $100 \mu \mathrm{EGM}-2 \mathrm{MV}$ 
was poured inside the ring and incubated at $37^{\circ} \mathrm{C}$ for $40 \mathrm{~min}$ for cell attachment. After this period, the cloning ring was carefully removed and the edges of the circle formed, were marked. One milliliter of medium (plus the various treatments) was then added. The cells were treated for 3 days and cell migration was assessed on the third day.

\section{Chemotaxis assay}

HMVEc $\left(10^{6}\right.$ cells) in $100 \mu$ LGM-2MV medium were plated on the underside of transwell membranes $(6.5 \mathrm{~mm}$ Transwell filter inserts; membrane pore size, $8 \mu \mathrm{m}$; Corning Costar Corporation, Corning, NY, USA) by inverting the insert. The cells were allowed to adhere for $30 \mathrm{~min}$, and then the wells were turned right side up and medium was added to both chambers: $100 \mu \mathrm{l}$ in the top chamber with $5 \mathrm{ng} / \mathrm{ml}$ bFGF alone, or bFGF plus U-PRL or S179D PRL $(1 \mu \mathrm{g} / \mathrm{ml}) ; 1 \mathrm{ml}$ in the bottom chamber with EGM$2 \mathrm{MV}$ only. The cells were allowed to migrate towards the bFGF for $4 \mathrm{~h}$. In order to evaluate migration, the cells on the undersides of the chambers were removed by wiping them away with a cotton swab, and the membranes were then fixed and stained with $2 \%$ toluidine blue in $4 \%$ formaldehyde. Migrated cells on top of the filter were photographed and counted in ten fields per filter at $\times 10$ magnification to obtain the average relative number of migrating cells per treatment (Li et al. 2004).

\section{Establishment of rat aorta culture}

The proximal aorta was obtained from adult SpragueDawley rats as described previously by Wang et al. (2004), and $1 \mathrm{~mm}$ rings were sectioned. Twenty-fourwell plates were pre-coated with $200 \mu 1$ Matrigel (BD Biosciences) diluted 1:1 with EGM-2MV. An aortic ring was placed on the top of this layer and covered with additional Matrigel $(200 \mu \mathrm{l})$. After Matrigel polymerization, $500 \mu \mathrm{l}$ EGM-2MV containing $2 \%$ FBS (medium for preferential growth of endothelial cells according to Wang et al. (2004)) were added to each well and the rings were incubated for $24 \mathrm{~h}$. After this incubation, fresh medium was added with either U-PRL or S179D PRL ( 1 or $2 \mu \mathrm{g} / \mathrm{ml}$ ), and incubation continued for 8-10 days.

\section{Qualitative and quantitative measurement of cell out-growth in the aorta ring assay}

Qualitative assessment was performed as described previously (Wang et al. 2004) with MTT (3-(4,5dimethylthiazol-2-yl)-2,5-diphenyl-2- $H$-tetrazolium bromide) staining. Quantitative assessment used an MTS (3-(4,5-dimethylthiazol-2-yl)-5-(3-carboxymethoxyphenyl)-2H-tetrazolium) assay to measure the relative number of viable cells growing from the aorta rings. After removal of the ring of aorta, $300 \mu \mathrm{l}$ freshly prepared solution containing $100 \mu \mathrm{g}$ MTS and $1 \mu \mathrm{g}$ PMS (phenazine methosulfate) in DPBS was added to each well and incubated for $24 \mathrm{~h}$ at $37^{\circ} \mathrm{C}$. The medium used for this study preferentially selects for endothelial out-growth, but cell number will include some fibroblasts and smooth muscle cells (Hata-Sugi et al. 2002).

\section{Gene expression by semi-quantitative and real-time RT-PCR}

Total RNA from non-confluent HUVEc $\left(2 \times 10^{6}\right.$ cells/ $100 \mathrm{~mm}$ dish) was isolated with Trizol (Gibco/Invitrogen). The primers used for RT-PCR are given in Table 1. Expression was normalized to GAPDH mRNA for semi-quantitative RT-PCR, and to $\beta$-actin for real-time RT-PCR.

\section{Semi-quantitative $R T$-PCR}

Five micrograms of total RNA from each sample were used for cDNA synthesis using Super Script First Strand Synthesis (Invitrogen). A total volume of $2 \mu \mathrm{l}$ cDNA from the RT reaction was used with the PCR Master Mix (Invitrogen). The amplification program consisted of $95^{\circ} \mathrm{C}$ for $2 \mathrm{~min}$, followed by 30 cycles consisting of a denaturation step $\left(95^{\circ} \mathrm{C}\right.$ for $\left.30 \mathrm{~s}\right)$, an annealing step $\left(55\right.$ or $56^{\circ} \mathrm{C}$ ) and an extension step $\left(72^{\circ} \mathrm{C}\right.$ for $\left.30 \mathrm{~s}\right)$. The amplified products were detected by $1 \%$ agarose/Tris-borate EDTA (TBE) $(0.089 \mathrm{M}$ Tris and borate, $0.002 \mathrm{M}$ Na-EDTA) gel electrophoresis and ethidium bromide staining.

\section{Quantitative real-time $R T-P C R$}

Twenty five microliter reactions were prepared in 96-well optical reaction plates (ABI Prism; Applied Biosystems) using SYBR green master mix (Applied Biosystems, Foster City, CA, USA). Using the ABI Prism 7700 (Applied Biosystems), samples were heated to $50^{\circ} \mathrm{C}$ for $2 \mathrm{~min}$, then $95^{\circ} \mathrm{C}$ for $10 \mathrm{~min}$, before 40 cycles at $95^{\circ} \mathrm{C}$ for $15 \mathrm{~s}$ and then 55 or $56^{\circ} \mathrm{C}$ for $1 \mathrm{~min}$. Real-time data were analyzed using the comparative $C_{\mathrm{T}}$ method (Bustin 2000).

\section{Protein array}

In order to detect the influence of S179D PRL on the release of angiogenesis-related factors, an angiogenesis antibody array was used (Chemicon International, 
Table 1 Oligonucleotide sequences employed

\begin{tabular}{|c|c|}
\hline Primer name & $5^{\prime}$-Oligonucleotide sequence-3' \\
\hline PRLR-LF-reverse & GATTTGATGCTCATCTGTTGGA \\
\hline PRLR-LF-forward & TCCAGGTATGTGGGTTTCAT \\
\hline $\begin{array}{l}\text { PRLR-deleted- } \\
\text { LF-forward }\end{array}$ & ATCATGATGGTCAATGCCACTA \\
\hline $\begin{array}{l}\text { PRLR-deleted- } \\
\text { LF-reverse }\end{array}$ & TGGGGTTCCTCACACTTTTC \\
\hline PRLR-SF1A-reverse & GATAGTGAGGACCAGCATCTAATG \\
\hline PRLR-SF1A-forward & TGGACTGTGGTCAATGTTGC \\
\hline PRLR-SF1B-reverse & CATGAATGATACAACCGTGTGG \\
\hline & CAACATCAAGGGGTCACCTC \\
\hline PRL-EXON2 & GCAGTTGTTGTTGTGGATGATT \\
\hline PRL-EXON5 & GATGCCAGGTGACCCTTCGAGA \\
\hline BETA & ACAC \\
\hline BETA ACTIN-reverse & GTCATACTCCTGCTTGCTGAT \\
\hline CTGF-forward & GAGGAAAACATTAAGAACGGCAAA \\
\hline CTGF-reverse & CGGCAC \\
\hline TIMP-1 forward & CTGCGGATACTTCCACAGGTC \\
\hline TIMP-1 reverse & GCAAGAGTCCATCCTGCAGTT \\
\hline TIMP-2 forn & TTGAGAGT \\
\hline TIMP-2 reve & CTGGCAACCCTACAACAGACCC \\
\hline IL-8 forward & ATAAGCAGGCCTCCAACGC \\
\hline IL-8 reverse & $\mathrm{ACC}$ \\
\hline VEGF-forward & CTCCA \\
\hline VEGF-reverse & CAAGGCCCACAGGGATTTT \\
\hline $\mathrm{HO}-1$-forward & CAGGCAGAGAA \\
\hline HO-1-reverse & GATGTTC \\
\hline TSP-1-forward & CССTTCAAAACAAATAGGAGTTCA \\
\hline TSP-1-re & CCAAATGCCAG \\
\hline ANG-2-forward & CTTCA \\
\hline ANG-2-reverse & GTAAGCCTCATTCCCTTCCC \\
\hline ANG- & GCAACTGC \\
\hline ANG-1reverse & CATCTGCACAGTCTCTAAATGGT \\
\hline FGF-forward & TGTGCTAACCGTTACCTGGCT \\
\hline FGF-reverse & GCCACATACCAACTG \\
\hline ANGIOGENIN-forn & TGGGCGTTTTGTTGTTGGTCTTC \\
\hline ANGIOGENIN-reverse & CGTTTCTGAACCCCGCTGTGG \\
\hline FGFR-reverse & GCCAGCAGTCCCGCATCATCAT \\
\hline FGFR-forward & GACGCAACAGAGAAAGACTTGT \\
\hline VEGFR-1-reverse & GATGTAGTCTTTACCATCCTG \\
\hline VEGFR-1-forward & CAAGTGGCCAGAGGCATGGAGTT \\
\hline VEGFR-2-reverse & TGCCAGCAGTCCAGCATGGTCTG \\
\hline VEGFR-2-forward & GAGGGCCTCTCATGGTGATTGT \\
\hline GAPDH-reverse & GGCATGGACTGTGGTCATGAG \\
\hline GAPDH-forward & TGCACCACCAACTGCTTAGC \\
\hline
\end{tabular}

Inc.Temecula, CA, USA; CHEMIARRAY human angiogenesis antibody array). For this assay, a control consisting of HUVEc cultured in SFM plus bFGF $(2.5 \mathrm{ng} / \mathrm{ml})$ and EGF $(1 \mathrm{ng} / \mathrm{ml})$, and a treatment group with the same medium plus S179D PRL $(1 \mu \mathrm{g} / \mathrm{ml})$, was used. The conditioned medium was then retrieved after a $24-h$ incubation. Serum-free medium was chosen to reduce the background quantities of angio-active compounds. Normalization from array to array utilized the positive control included by the manufacturer for this purpose.

\section{Statistical analysis}

All numerical data are presented as the mean \pm s.E. Except where noted, all experiments used at least triplicates and were conducted a minimum of three times. Statistical significance was calculated using Student's $t$ test to compare individual means with or without Bonferroni corrections, as appropriate. A $P$ value of $<0.05$ was considered significant. For the corneal angiogenesis assay, the two groups were compared by Mann-Whitney test.

\section{Animal subjects}

All procedures involving the use of animals received prior approval from institutional committees and were in accordance with guidelines from the American Association for Laboratory Animal Care, the United States Department of Agriculture and the National Institutes of Health (NIH).

\section{Results \\ In vivo assays}

The chick CAM assay allowed investigation of the effects of U-PRL and S179D PRL in vivo in a tissue undergoing a normal angiogenic process. U-PRL had no discernable effect and hence was chosen as the control for purposes of illustration (Fig. 1). The inhibitory effect of S179D PRL on this angiogenic process is evident: apart from the original two blood vessels between which the pellets were placed, the samples treated with S179D PRL were essentially devoid of blood vessels within the area occupied by the pellet. Even beyond the perimeter of the pellet, the vessels appeared less substantial than their counterparts in the U-PRL control. The anti-angiogenic effects were quantified to produce Fig. 1C, where the avascular area within the pellet perimeter was measured. The anti-angiogenic activity of S179D PRL was almost completely reversed by the presence of an anti-PRL antibody.

In addition to testing the anti-angiogenic activity in the chick embryo system, S179D PRL was tested in the mouse corneal angiogenesis assay. In this assay, the normally avascular cornea develops blood vessels in response to an angiogenic compound such as bFGF. The bFGF is placed in a slow-release hydron pellet and a second pellet containing the potential anti-angiogenic material is placed alongside. The great sensitivity of 


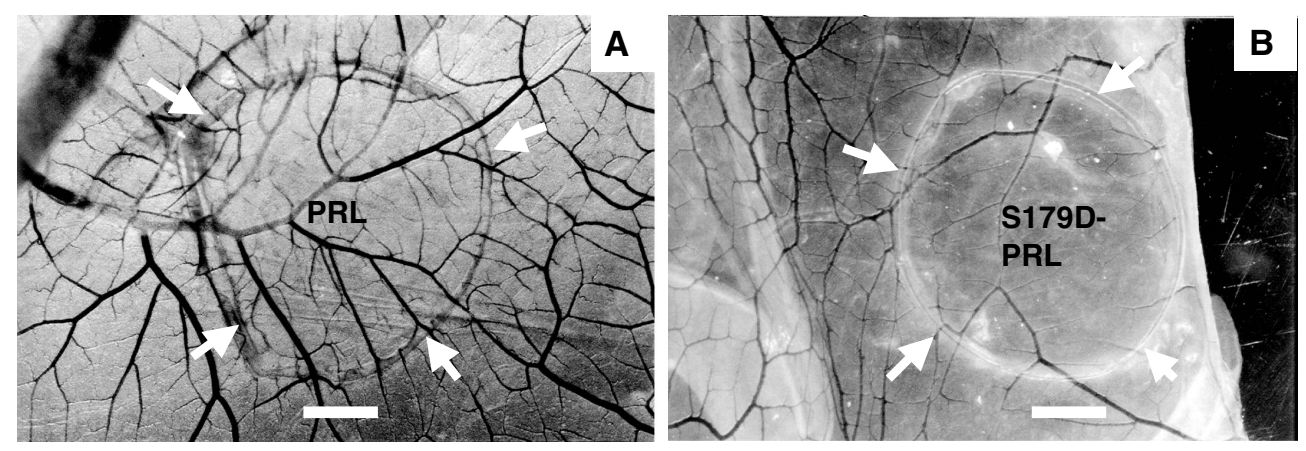

C

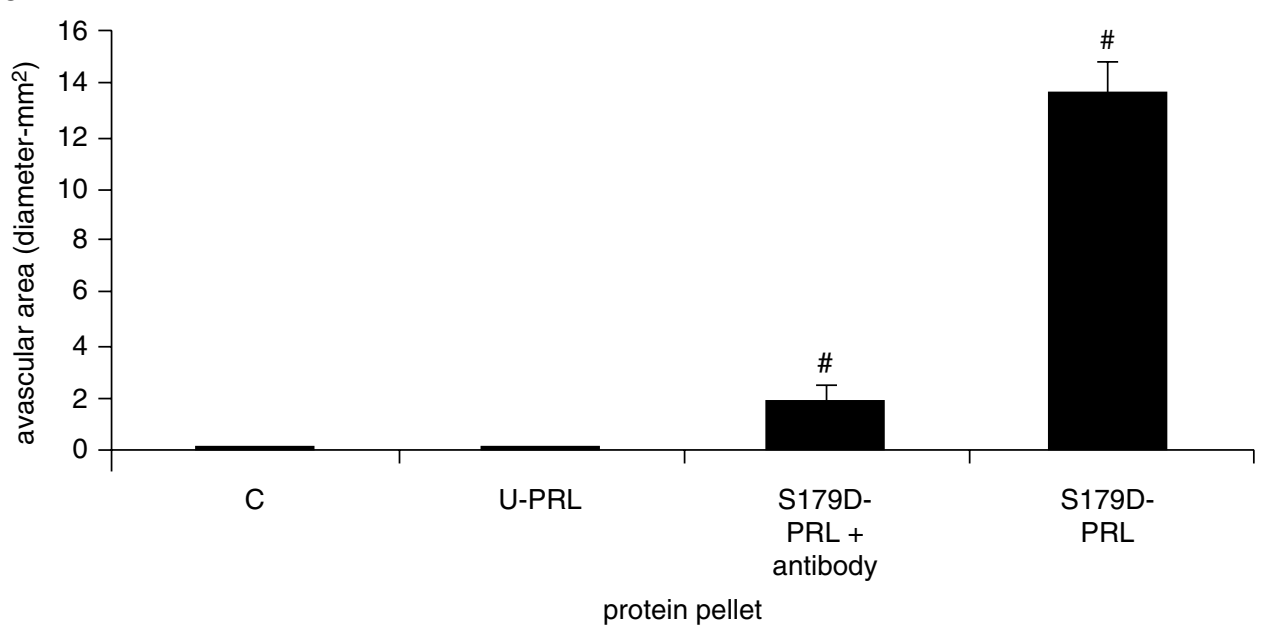

Figure 1 Effects in the CAM assay. (A) U-PRL-treated CAM was indistinguishable from the untreated CAMs. (B) S179D PRL-treated CAM. The white arrows mark the edges of the pellets, which contained a total of $1 \mu \mathrm{g}$ in the case of each PRL and $500 \mathrm{ng}$ bFGF. (C) Quantification of the avascular area and results of blockade of the effect of S179D PRL with an antibody. ${ }^{\#} P<0.01$ versus saline control (C) or U-PRL.

this assay also allowed us to analyze much lower concentrations of S179D PRL. Because U-PRL had no angiogenic activity in the previous assay and preliminary experiments demonstrated no angiogenic activity in vitro, it was used in this part of the study as a control that differed from the S179D PRL by only one amino acid. As shown in Fig. 2, as little as $52 \mathrm{ng} \mathrm{S179D}$ PRL were able to reduce angiogenesis in response to $90 \mathrm{ng}$ bFGF, by $50 \%$. On a molar basis the S179D PRL was present at half the concentration of bFGF.

\section{Effects on endothelial cell number}

Since S179D PRL proved to be anti-angiogenic in vivo, the next set of studies was designed to examine the mechanism. First, we asked what forms of the PRLR were expressed by human endothelial cells. Figure 3A illustrates PCR products designed to be specific for the long form and for both short forms of the human PRLR by recognition of the alternately spliced intracellular regions. The form-specific amplicons were sequenced in order to verify their identity. Figure 3B illustrates that the mRNA for both short forms is translated into protein recognizable by antibodies directed against the extracellular domain of the receptor. No band at the expected molecular mass for the long form was observed even though $1 \mathrm{mg}$ protein was subjected to immunoprecipitation. Subsequent experiments determined that a significant proportion of what we had identified as the long form by PCR was missing part of the extracellular domain of the receptor, and hence was unlikely to be detected with the antibody used. Figure 3C shows the result of PCRs that indicate the presence of full-length long receptor (FLF) and a version of the long receptor with part of the extracellular domain deleted (DLF). Careful analysis of the structure and signaling capabilities of this form of the receptor is the subject of continued 

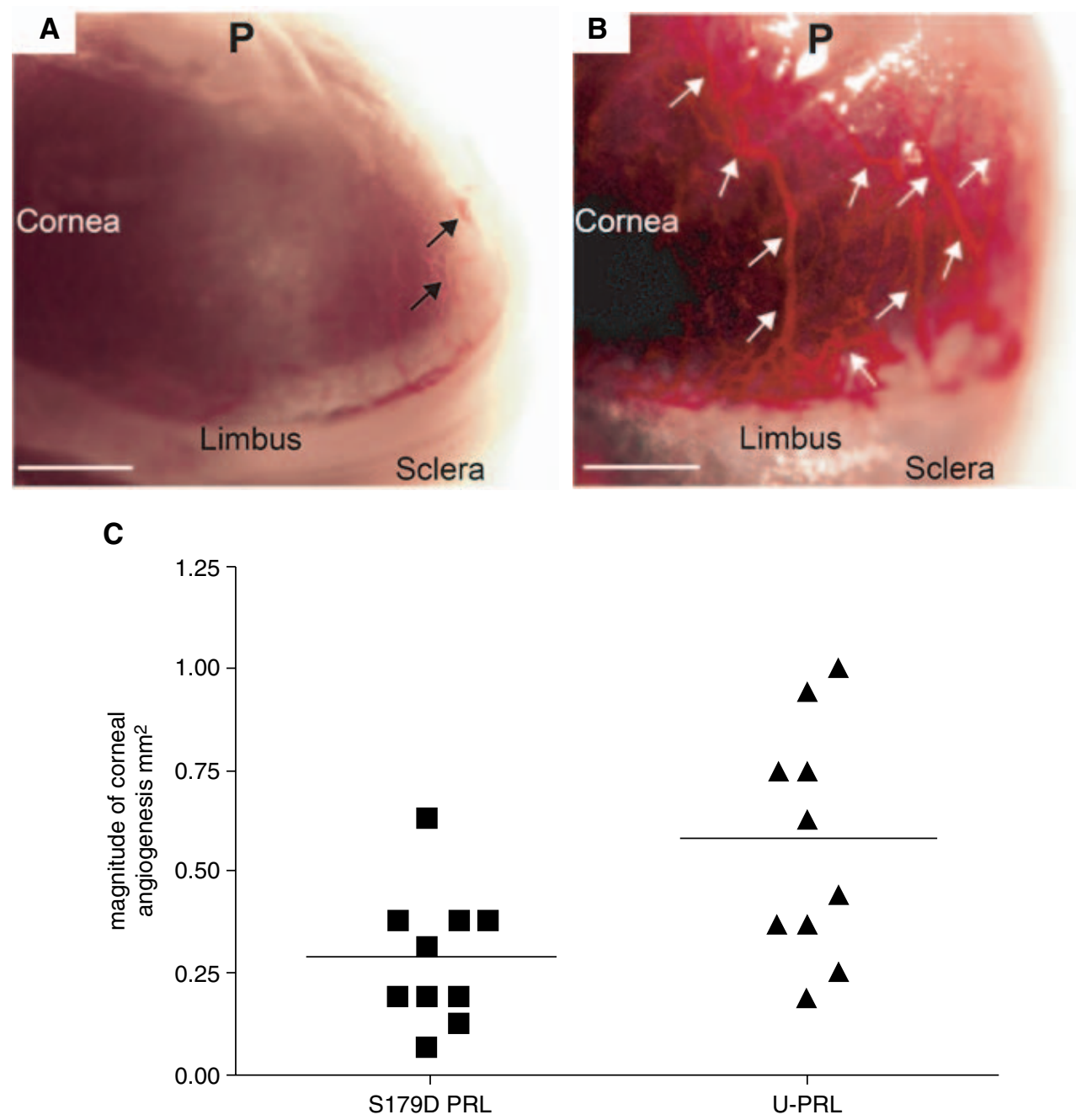

Figure 2 S179D PRL is anti-angiogenic in the dual hydron pellet mouse cornea assay. (A) Scarcity of bFGF-induced (90 ng/pellet) angiogenic vessels in a S179D PRL-treated (52.5ng per pellet) cornea. (B) Abundance of bFGF-induced angiogenic vessels in a U-PRL-treated (52.5 ng per pellet) cornea (control). Arrows indicate vessels penetrating the cornea from limbus. $P$ denotes the location of the implanted hydron pellets. Scale bar, $250 \mu \mathrm{m}$ in A and B. (C) The magnitude of angiogenesis induced by bFGF was significantly smaller $\left(0.2827 \mathrm{~mm}^{2}\right)$ in corneas implanted with S179D PRL-containing hydron pellets compared with those treated with hydron pellets containing U-PRL $\left(0.5717 \mathrm{~mm}^{2}\right)$ (Mann-Whitney test, $\left.P=0.0147\right)$.

investigation, but a delta $\mathrm{S} 1$ version of the long receptor has been previously reported in a wide variety of tissues (Kline et al. 2002).

To determine the effect of S179D PRL on endothelial cell number, an assay was conducted that measured viable cell number after a 3-day incubation. In order to survive and proliferate in culture, human endothelial cells require the presence of bFGF, sufficient heparin for the bFGF to be biologically active and either serum or EGF. The effect of S179D PRL was therefore over and above the effect of these angiogenic medium components. As shown in Fig. 4A, high concentrations $(500-1000 \mathrm{ng} / \mathrm{ml})$ of S179D PRL caused a decrease in viable cell number. In most assays, the response was modest at $25 \%$ (as illustrated), but was as large as $40 \%$ on occasion. Lower concentrations of S179D PRL were without significant effect in this 3-day incubation. High concentrations of U-PRL were also without effect. This served as one measure of the specificity of the response since U-PRL and S179D PRL only differ by one amino acid and each is made by recombinant technology in Escherichia coli. Since both molecules are expressed at very similar levels during production, they are therefore likely to contain very similar levels of contaminating substances. Because of the sensitivity of endothelial cells 
A

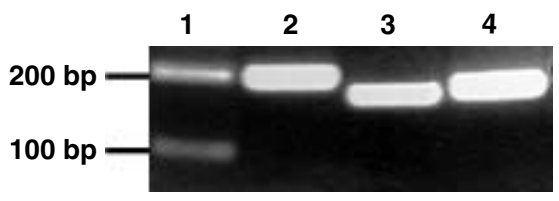

B

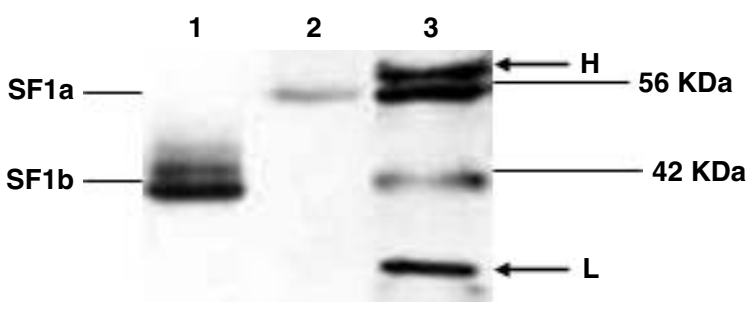

C

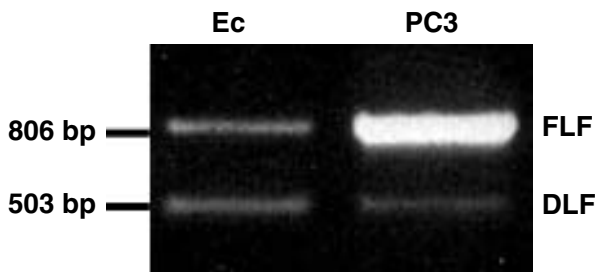

Figure 3 Expression of PRLR in HUVEc. RT-PCR (A) and immunoprecipitation and Western blotting (B) for the PRLR isoforms. (A) Lane 1 contains a base pair ladder; lane 2, the long PRLR product (200 bp); lane 3, the short PRLR 1a product (174 bp); lane 4, the short PRLR 1b product (179 bp). (B) Lanes 1 and 2 show lysates of HEK cells transfected with equal amounts of vector coding for the short $1 \mathrm{~b}$ form and short $1 \mathrm{a}$ form of the PRLR respectively to provide positive controls; lane 3 shows the untreated HUVEc immunoprecipitated extract. $\mathrm{H}$, heavy chain; $\mathrm{L}$, light chain; SF1a, short form 1a; SF1b, short form $1 \mathrm{~b}$. The numbers to the right indicate the molecular masses calculated from co-run molecular mass markers. (C) PCR amplicons from HMVEc which result from the presence of full-length and extracellularly deleted versions of the long form of the receptor. FLF, amplicon from the full-length long form of the receptor; DLF, amplicon from the extracellularly deleted long form of the receptor. Human prostate cancer cell line (PC3), PC3 cell positive control for the expression of the full-length long form; Ec, endothelial cell.

to bacterial endotoxins and the high concentrations of S179D PRL required to see an effect in the 3-day incubation, we measured the levels of endotoxin in each PRL and performed an endotoxin control. The level of endotoxin in the two recombinant PRLs was similar at less than $0.00166 \mathrm{EU} / \mu \mathrm{g}$ protein. An endotoxin control performed at more than 10 -fold this concentration was without effect on viable cell number (labeled ' $L$ ' in Fig. 4A).

To be sure that the activity of S179D PRL was not due to the presence of misfolded protein (this occurs more frequently with S179D PRL than U-PRL), conditioned medium from eukaryotic cells overexpressing each PRL was also analyzed (shaded bars in Fig. 4A). Eukaryotic cells have a number of quality control steps that eliminate misfolded proteins from the secretory pathway and a variety of chaperone proteins aid in the proper folding of secreted proteins (Krishna et al. 2004). The PRLs expressed in eukaryotic cells had indistinguishable activity from those expressed in E. coli. A final control conducted was to pretreat the E. coli proteins with $10 \mu \mathrm{g} / \mathrm{ml}$ polymyxin-B. Polymyxin $\mathrm{B}$ binds and inactivates endotoxin. This also did not change the activity of the S179D PRL (Fig. 4B). We conclude therefore that although the effect of S179D PRL on human endothelial cells requires high concentrations under the conditions used, it is a specific response.

Analysis of DNA content at the end of the 3-day incubation period in S179D PRL indicated an 8-fold increase in the percentage of cells with sub $G_{0} / G_{1}$ quantities of DNA (Fig. 4C). Thus, cell death contributed to the decreased cell number. Once again, the endotoxin control showed no effect.

\section{Effects on cell migration}

In order to form blood vessels, endothelial cells have to be capable of migrating. We therefore tested the ability of S179D PRL to affect cell migration with and without a chemoattractant. New capillaries are most often formed from microvessels and so HMVEc were initially used for this part of the study. When HMVEcs were plated inside a cloning ring and subsequently allowed to migrate, S179D PRL reduced the distance migrated by about $40 \%$ (Fig. 5A). Since the distance migrated in this 3-day assay would have been affected by the number of cells and we know that S179D PRL reduces the number of HMVEc (data not shown) as well as HUVEc, we also performed a shorter-term, $4 \mathrm{~h}$ chemotaxis assay. In this assay, S179D PRL reduced the migration of HMVEc in response to bFGF by more than $60 \%$ (Fig. $5 \mathrm{~B}$ ).

Another measure of migration is the ability to form tubules when plated in Matrigel. Randomly plated cells must digest their way through the Matrigel and arrange themselves into tubular structures. S179D PRL decreased the ability of HUVEc to form tubule structures in Matrigel (Fig. 5C).

Although HUVEc and HMVEc are considered primary cells and were mostly used at passage numbers up to 5, we wanted to test the effect of S179D PRL on the migration of endothelial cells that had never been cultured. To do this, we analyzed the outgrowth of 
A

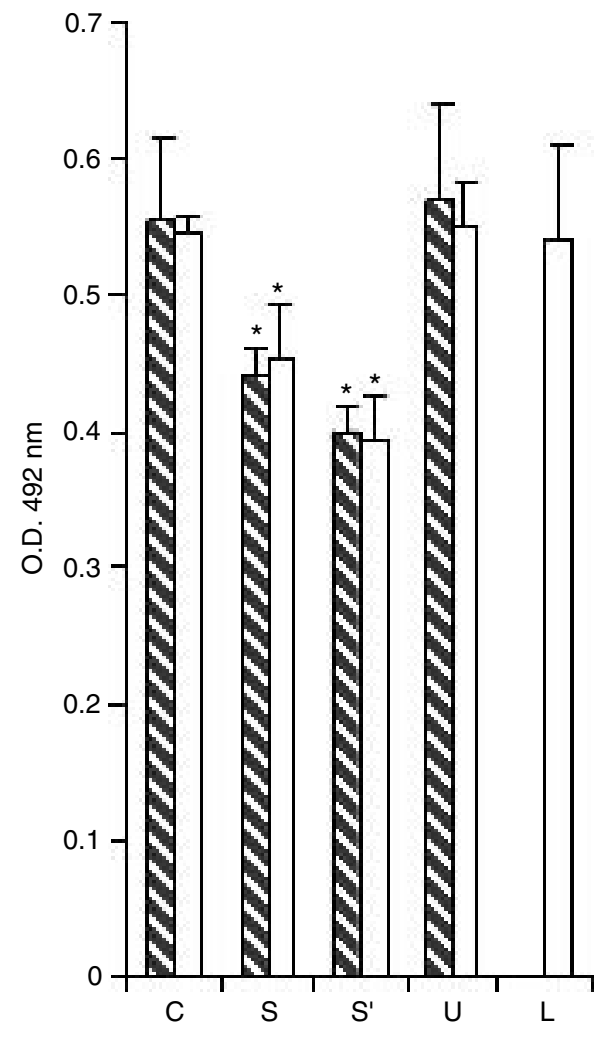

B

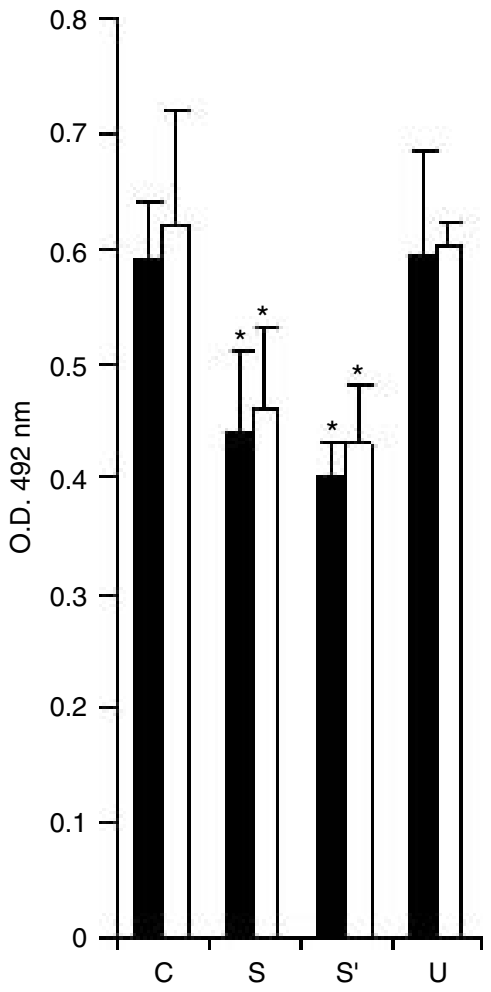

C

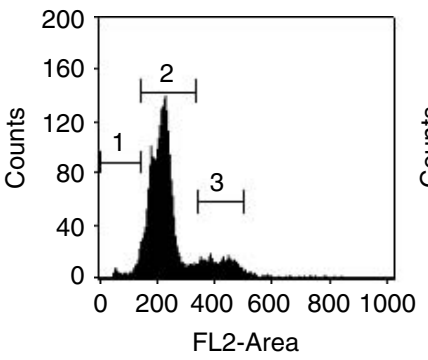

C

$1-2.1 \pm 1.1 \%$

$2-77.7 \pm 0.78 \%$

$3-13.9+1.9 \%$

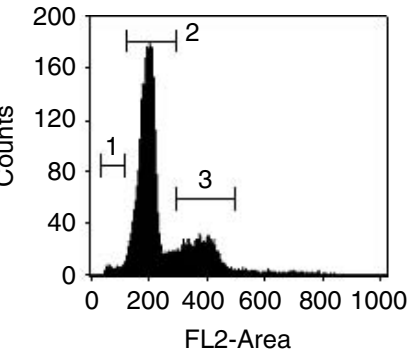

LPS

$1-2.3 \pm 0.4 \%$

$2-84.1 \pm 1.3 \%$

$3-10.3 \pm 1.2 \%$

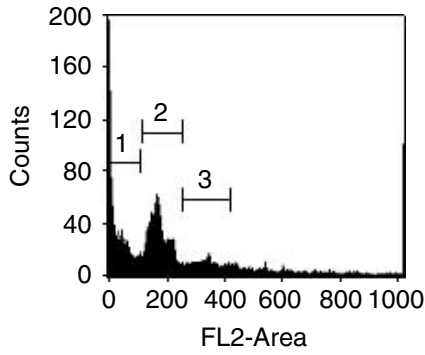

$\mathrm{S}$

$1-25.7 \pm 2.4 \%$

$2-62.9 \pm 1.5 \%$

$3-6.0 \pm 1.4 \%$

Figure 4 Effects on HUVEc number and DNA content. (A) The response to $500 \mathrm{ng} / \mathrm{ml}(\mathrm{S})$ and $1 \mu \mathrm{g} / \mathrm{ml}$ (S\{'\}) S179D PRL, U-PRL at $1 \mu \mathrm{g} / \mathrm{ml}(\mathrm{U})$ or endotoxin at $0.02 \mathrm{EU} / \mathrm{ml}$ (10 times the concentration in the recombinant protein preparations) (L) were without effect. The open bars show the recombinant protein expressed in $E$. coli and the shaded bars, the same concentrations of proteins expressed in eukaryotic cells. (B) Result with recombinant proteins from E. coli with (filled bars) and without (open bars) prior incubation with polymyxin B. (C) Results of flow cytometric analysis following propidium iodide staining of control cells (C), cells treated with $0.02 \mathrm{EU} / \mathrm{ml}$ endotoxin (LPS) and cells treated with S179D PRL (S) for 3 days. On the graphs, 1 is sub $G_{0} / G_{1}$ amounts of DNA, most often interpreted as resulting from apoptosis; 2 is $G_{0} / G_{1} ; 3$ is $G_{2} / M$.

endothelial cells from rings of aorta placed in primary culture. Endothelial and associated cells migrate from the intima to form sprouts of capillary-like structures. Observation of sprout formation after 8 days showed a marked reduction in the samples treated with S179D PRL (Fig. 5D). Upon removal of 
A

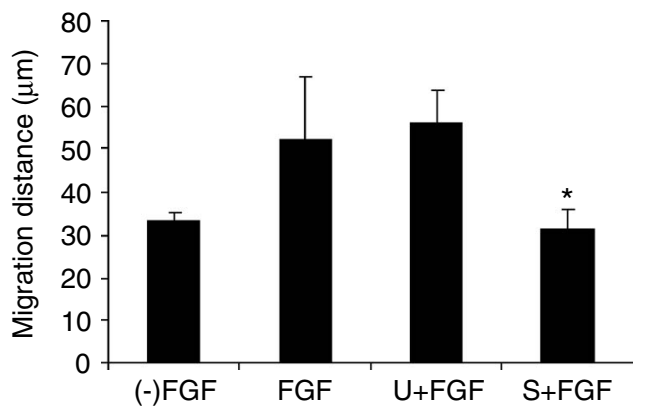

B

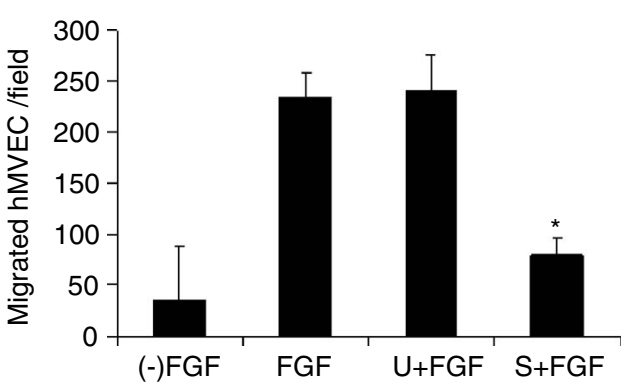

C

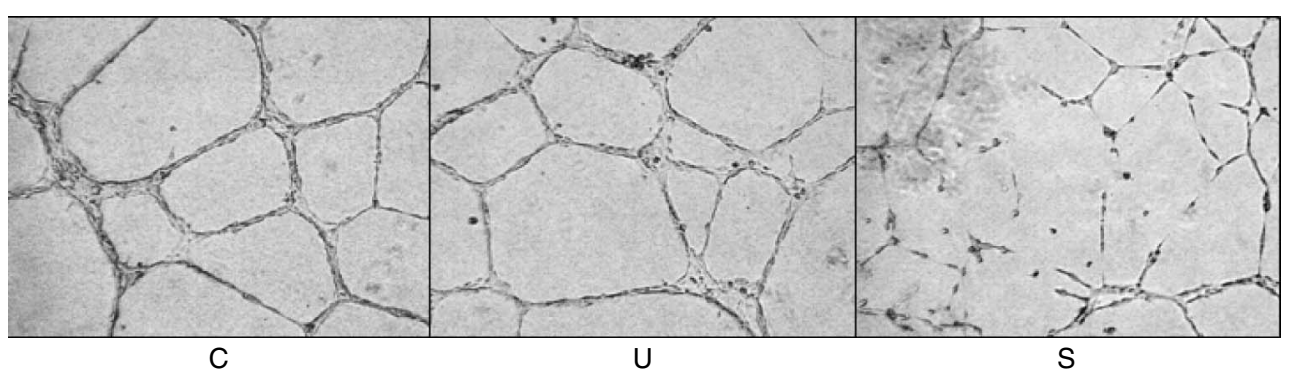

D

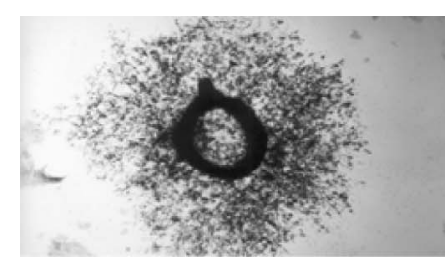

C

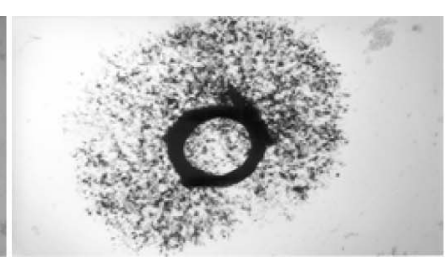

U

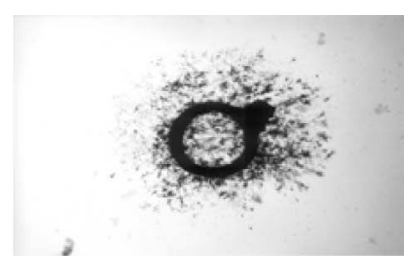

S

$\mathbf{E}$

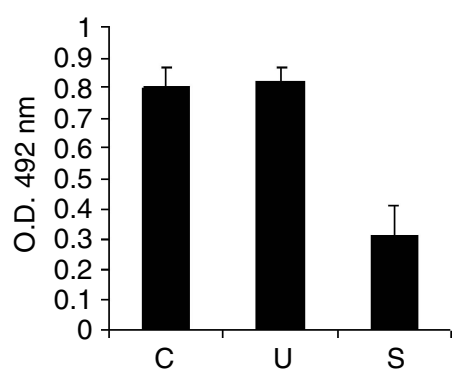

Figure 5 Effects on endothelial cell migration and tubule formation. (A) The distance migrated in a 3-day incubation period; (B) The relative number of cells that have migrated in response to a gradient of bFGF during a 4-h period. (C) The ability of endothelial cells to form themselves into tubule-like structures in the absence and presence of either U-PRL or S179D PRL. Each form of PRL was used at $1 \mu \mathrm{g} / \mathrm{ml}$ for panels A to C. (D) The effect of each form of PRL (2 $\mu \mathrm{g} / \mathrm{ml})$ on vessel sprout formation from rat aortas. (E) Quantification of the relative number of cells in the sprouts. ${ }^{*} P<0.05$ versus bFGF control in both panels $\mathrm{A}$ and $\mathrm{B}$. Abbreviations as in previous figures.

the original ring of aorta, the cells that have grown out can be quantified by formazan dye conversion assays. The results in Fig. 5E indicate that a 50\% decrease in relative cell number occurred with S179D PRL. Thus it seems clear that S179D PRL affects both the number of viable endothelial cells and the migratory capacity of endothelial cells from large vessels and microvessels alike. 
A
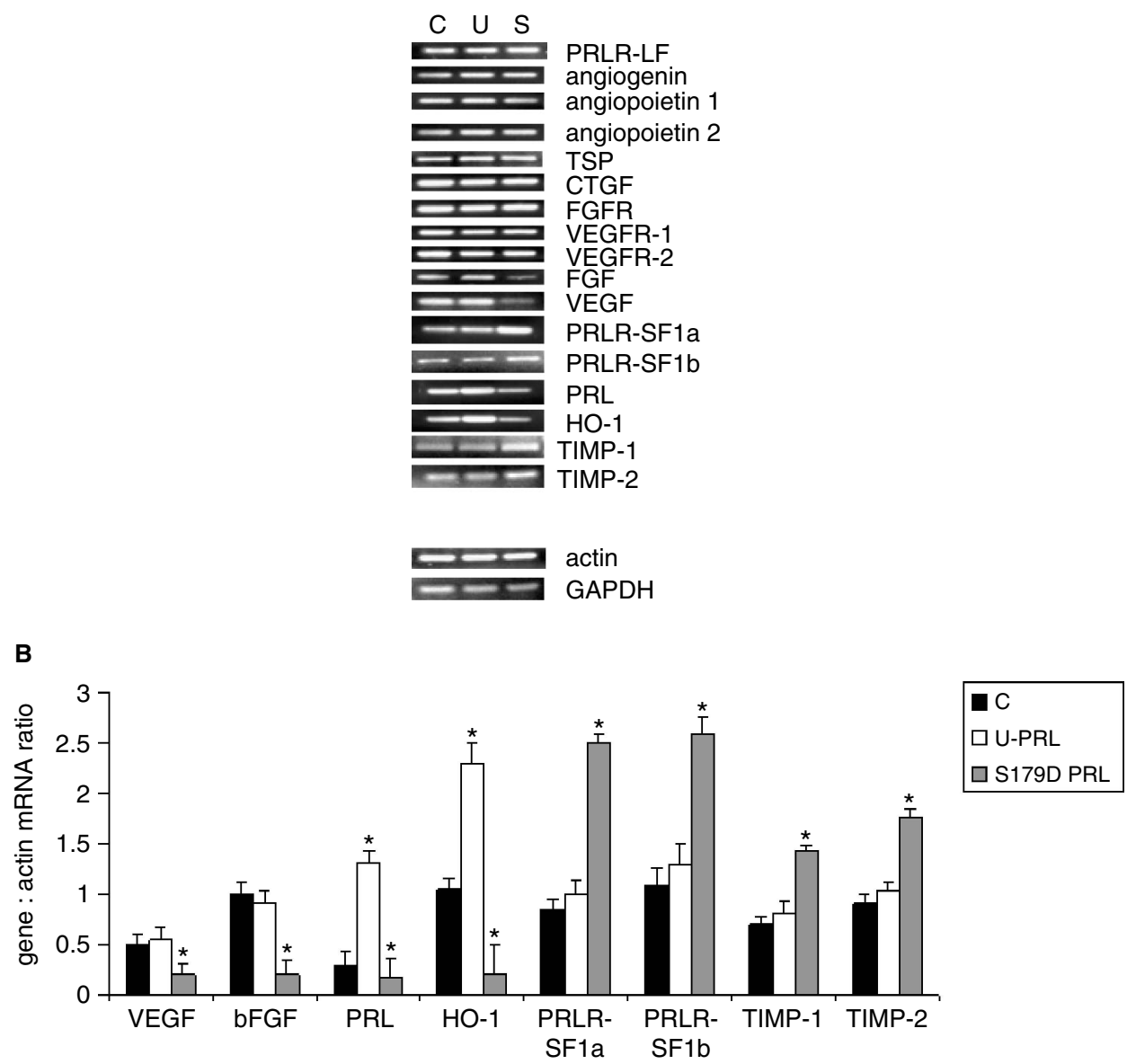

Figure 6 Effects of each form of PRL $(1 \mu \mathrm{g} / \mathrm{ml})$ on mRNA expression in HUVEc. (A) Results of semi-quantitative PCR for 17 genes of interest and 2 control genes for normalization purposes (GAPDH and actin). TSP, thrombospondin; CTGF, connective tissue growth factor; VEGF, vascular endothelial growth factor; HO-1, heme-oxygenase-1; TIMP-1 and -2, tissue inhibitors of matrix metalloproteases 1 and 2. (B) Results of real-time PCR for the 8 genes most affected by treatment. ${ }^{\star} P<0.05$ versus control $(\mathrm{C})$.

\section{Effects on gene expression (mRNA)}

To determine the mechanism whereby U-PRL and S179D PRL had such different effects on endothelial cells, we analyzed expression of PRLR and a variety of angiogenesis-related molecules. As illustrated in Fig. 6A, which shows the results of semi-quantitative PCR, U-PRL and S179D PRL had different effects on the expression of a number of genes. In this battery of tests, U-PRL increased expression of endogenous PRL and heme-oxygenase-1, but otherwise was without significant effect. This is illustrated more quantitatively in Fig. 6B where the results of real-time PCR are presented for the 8 of the 17 mRNAs most affected by treatment. U-PRL increased the expression of endogenous PRL by about 4-fold and doubled the expression of heme-oxygenase-1. Production of PRL by HUVEc has been previously reported (Clapp et al. 1998, Corbacho et al. 2000). In contrast to U-PRL, S179D PRL down-regulated the expression of endogenous PRL (about one-half) and heme-oxygenase-1 (about one-fourth), had no effect on the expression of what we labeled the long PRL receptor (which would include both the full-length and the deleted version) and up-regulated (doubled) both short forms of the PRLR. S179D PRL also down-regulated expression of bFGF (about one-fourth) and vascular endothelial growth factor (VEGF; about one-half), without significant effect on the expression of their receptors. Thrombospondin, angiogenin, angiopoietins 1 and 2, and connective tissue growth factor were unaffected at the mRNA level. Thrombospondin and connective 


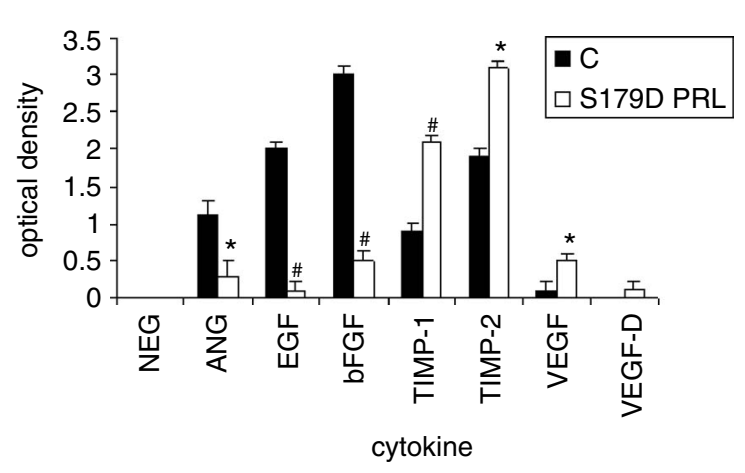

Figure 7 Effects of S179D PRL $(1 \mu \mathrm{g} / \mathrm{ml})$ on 24-h release of angio-active molecules in HUVEc. Quantification is from two arrays, each one containing two spots for each protein. NEG, negative control on the array; ANG, angiogenin. ${ }^{*} P<0.05$ versus control; ${ }^{\#} P<0.01$ versus control.

tissue growth factor were included because expression of these two genes has been shown to be affected in the mammary gland of mice treated with S179D PRL (Naylor et al. 2005).

\section{Effects on protein release}

The 24-h conditioned medium was analyzed by protein array to test whether effects on gene expression were translated into effects on normally secreted proteins. The 24-h time point was chosen so as not to complicate analysis with the effects of non-specific release caused by apoptosis. Figure 7 illustrates results for all of the proteins on the array that corresponded to the gene expression analyses. S179D PRL decreased release of angiogenin, EGF and bFGF. For the latter two, the effect may have been even more pronounced than is indicated in the figure since both bFGF and EGF were present at low levels as part of the culture medium. S179D PRL therefore affects the amount of several angiogenic proteins secreted, thereby decreasing the probability that they will interact with their cognate receptors, forming an autocrine growth loop.

Of the other angio-active compounds examined at the protein level, the release of three of them was elevated by treatment with S179D PRL. These were the tissue inhibitors of metalloprotease 1 and 2, and surprisingly, VEGF.

\section{Effects of S179D PRL on signaling from bFGF}

After $16 \mathrm{~h}$ in the absence of bFGF, re-addition of bFGF initiates phosphorylation of ERKs 1 and 2 in HUVEc (Fig. 8A). The levels of phosphorylated ERKs were high from 5 to $30 \mathrm{~min}$ of incubation, declined to basal levels by $60 \mathrm{~min}$ and remained low through $300 \mathrm{~min}$. When S179D PRL was present, bFGF showed no ability to activate ERK between 0 and $30 \mathrm{~min}$, but the combination showed strong activation of ERK at $60 \mathrm{~min}$ and activation above control levels through $240 \mathrm{~min}$ (Fig. 8B). U-PRL and endotoxin were without effect on bFGF activation of ERK (data not shown). Since the gels and blots for Fig. 8A and B were run at different times in order to have a long time course, the ability of S179D PRL to inhibit ERK phosphorylation in response to bFGF at $30 \mathrm{~min}$ was confirmed using the same gel and blot (Fig. 8C).

\section{Discussion}

In this study we have shown for the first time that S179D PRL can be a potent anti-angiogenic compound, with its potency best illustrated in the mouse corneal angiogenesis assay. S179D PRL was effective when tested on human macro- and microvessel endothelial cells in vitro, and on chicken and rodent blood vessel development in vivo. In vitro assays demonstrated an effect on viable endothelial cell number and an effect on the ability of endothelial cells to migrate and form tubes reminiscent of capillaries. S179D PRL also interfered with the ability of endothelial cells to migrate in response to a chemoattractant. The chemotaxis assay was conducted in a 4-h time frame and so results were largely separate from effects on cell viability. Thus it seems that S179D PRL has two, separate, direct effects on endothelial cells: a reduction in viable cell number and an inhibition of migratory capacity. The reduction in viable cell number after a 3-day incubation correlated well with the number of cells containing sub $G_{0} / G_{1}$ amounts of DNA. By far the largest part of the effect on viable cell number, therefore, seems to be by the promotion of apoptosis.

Promotion of apoptosis can be brought about by removal of growth factors, and S179D PRL reduced expression or release of four very important endothelial growth factors: angiogenin, EGF, bFGF and VEGF. At the time points used, VEGF was reduced only at the mRNA level and angiogenin was reduced only at the protein level. Some of the effects on VEGF were unexpected. First, although VEGF mRNA was reduced at 3 days, the amount of protein in the medium was elevated at $24 \mathrm{~h}$. The angiogenin result suggests that this was not non-specific release. Instead, it may be an initial response to pre-apoptotic cell stress. One can reasonably expect, however, that with decreased mRNA there would later be decreased protein. Second, others have found that mixed PRL 
A

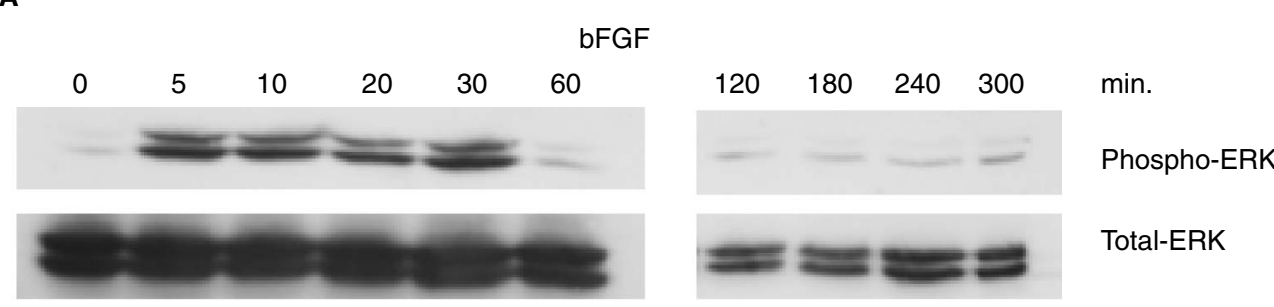

B

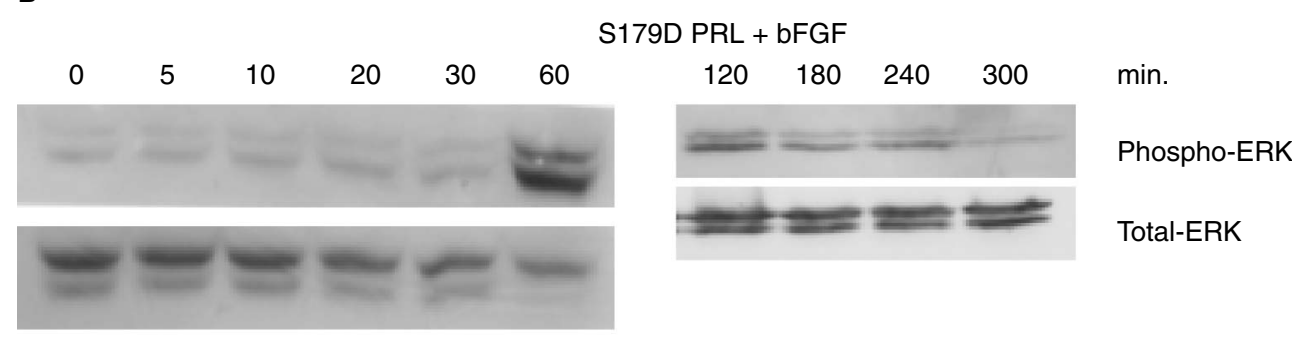

C

\begin{tabular}{lll}
$30 \quad 30 \quad 30$ & min. \\
\hline+2 & Phospho-ERK \\
\hline+2 & Total-ERK
\end{tabular}

$\begin{array}{rrrr}\text { S179D PRL } & - & - & + \\ \text { bFGF } & - & + & +\end{array}$

Figure 8 Effect of S179D PRL on signaling from bFGF. HUVEc were incubated without bFGF for $16 \mathrm{~h}$ and then bFGF (25 $\mathrm{ng} / \mathrm{ml})$ was re-supplied to the cells. (A) Time course between 0 and $300 \mathrm{~min}$ for bFGF activation of ERKs 1 and 2. (B) Results of co-incubation of bFGF with S179D PRL $(1 \mu \mathrm{g} / \mathrm{ml})$. Since the gels and blots shown in panels A and B were run at different times, panel $C$ shows a repeat of the result of co-incubation of S179D PRL and bFGF at the 30-min time point. The 0- to 60 -min lanes on panels $A$ and $B$ were run on the same gel and the $120-$ to $300-$ min lanes on panels $A$ and $B$ were run on the same gel.

preparations elevate mRNA for VEGF in other cell types (Hovey et al. 2001, Goldhar et al. 2005), whereas we observed either no effect of U-PRL or a decrease with S179D PRL. This difference may be related to the type of cell and therefore to the types of PRLR present: most cells primarily express the long form of the receptor; in our study we found that a substantial proportion of what we initially thought was long receptor was in fact missing part of the extracellular domain and hence would probably have a decreased ability to bind ligand. The predominant forms that could be recognized with an antibody against the extracellular domain of the receptor were the two short forms of the receptor. Since we saw no effect on expression of the long form receptor in response to either form of PRL and a substantial proportion of this is unlikely to bind PRL very well, it is likely that the signaling of relevance to the actions of both PRLs in endothelial cells originates at the short receptors.

Even though S179D PRL reduced VEGF, angiogenin, bFGF and EGF - thereby reducing the use of these autocrine growth loops - effects on cell number occurred in the presence of added bFGF and EGF because both are components of the culture medium. In addition, the anti-angiogenic effect seen in the corneal assay showed that S179D PRL could counteract the effect of bFGF. S179D PRL must therefore be able to block the effects of bFGF and not just its production. This was evidently not via an effect on the expression of the FGF receptor since no change in response to S179D PRL was observed, at least at the mRNA level. Since human PRL has been shown to bind to heparin (Khurana et al. 1999), one hypothesis we considered was that S179D PRL competed 
effectively with bFGF for heparin, while U-PRL did not. When we pre-incubated S179D PRL with heparin, however, it did not change its anti-angiogenic activity (data not shown) and hence we have excluded this as a mechanism. Next, we considered the possibility that S179D PRL interfered with signal transduction from bFGF. Our results show that S179D PRL did indeed block normal ERK activation by bFGF and yet also showed a delayed and prolonged activation of ERK. Prolonged activation of ERK has been associated in other cell systems with signaling to apoptosis (Liu et al. 1996, Lessor et al. 1998) and is consistent therefore with the effects of S179D PRL in these cells.

S179D PRL also decreased expression of endogenous U-PRL, but our data at this time are inconclusive about an autocrine growth-promoting role for PRL in endothelial cells, since we were unable to demonstrate any effect of additional U-PRL on cell number in vitro or angiogenesis in vivo. These results are in accord with those of Clapp et al. (1993) who saw no effect on HUVEc at the same dose and no effect in the CAM assay at 5-fold the dose we used. Using bovine endothelial cells, Struman et al. (1999) were also unable to see an angiogenic effect of PRL in vitro. However, they did observe an effect in the CAM assay at 20-fold the concentration used in our study, as long as the CAMs were mature and normal blood vessel development was complete (i.e. they were older than the CAMs used in our study). The only piece of data supporting a relevant function for U-PRL in the present study is the effect on heme-oxygenase-1. Hemeoxygenase-1 has been shown to be protective against apoptosis (Ohta \& Yachie 2004) and so, even though U-PRL did not increase the number of cells over those in the control, it may protect against apoptosis and, in that sense, be angiogenic under some circumstances. Consistent with this idea are the reports of anti-apoptotic effects of PRL in other cells (e.g. Kochendoerfer et al. 2003, Perks et al. 2004) and, conversely, the promotion of apoptosis by S179D PRL in other cells (Yang et al. 2002).

Others have demonstrated a long PRLR in bovine endothelial cells (Merckle et al. 2000), but the primers used would not have distinguished between the intact form and any forms missing part or all of the extracellular domain. It is possible therefore that bovine and other endothelial cells also express deleted versions of the long receptor. Up-regulation of the short forms by S179D PRL suggests that these varieties play a more important role in the antiangiogenic response. These short receptor isoforms are produced by differential splicing of the same initial transcript as the long form ( $\mathrm{Hu}$ et al. 2001,
Trott et al. 2003) and signaling through them by S179D PRL has previously been demonstrated in other cell types (Wu et al. 2003). As in the present study, this signaling resulted in long-term activation of ERK (Wu et al. 2003). At the same time, short-term activation of ERK in response to bFGF was inhibited. This result underscores the complex nature of intracellular signaling and the importance of long time-course analyses in response to ligands.

In vitro tubule formation, sprout formation and in vivo angiogenesis would each be decreased by the increased expression of the inhibitors of metalloproteases, as observed upon treatment with S179D PRL, since metalloproteases are required for migration through Matrigel and the outgrowth of sprouting vessels in vitro and in vivo (Chun et al. 2004).

In vivo blood vessel development involves the initial migration of endothelial cells and pericytes, in response to an angiogenic stimulus, followed by remodeling of the microvascular networks. During the process of neovascular sprouting, extensive cross-talk occurs between pericytes and endothelial cells (Folkman \& D'Amore 1996, Lindahl et al. 1997, Hellstrom et al. 2001, Enge et al. 2002, Bergers et al. 2003, Pietras \& Hanahan 2004, Baluk et al. 2005, Ozerdem 2005). S179D PRL therefore may also have direct or indirect effects on pericytes and other cells that contribute to the vessel wall. In this regard, the CAM assay results show that S179D PRL not only blocked initial development of vessels, but also appeared to limit wall development of pre-existing vessels. Although S179D PRL was very potent in vivo, the in vitro activities on HUVEc required much higher concentrations. This in part may reflect the need for a large and rapid effect in order for it to be seen in 3 days in vitro. It may also reflect important differences in the in vitro versus in vivo microenvironments. Additionally, it may suggest indirect mechanisms of action on cell types not present in the endothelial cell cultures, such as pericytes.

A cleaved and reduced form of PRL, so-called 16K PRL, has previously been reported to be antiangiogenic (Clapp \& Weiner 1992) and also seems to block ERK signaling from bFGF (Struman et al. 1999). S179D PRL is a more potent anti-angiogenic compound than $16 \mathrm{~K}$ PRL in vivo. It is efficacious at half the molar concentration of bFGF used in the corneal assay, while 16K PRL requires an 8-fold excess (Duenas et al. 1999). By contrast, 16K PRL is more effective in vitro (Clapp \& Weiner 1992, Clapp et al. 1993), perhaps suggesting a greater focus of $16 \mathrm{~K}$ PRL on endothelial cells themselves. Other members of the PRL superfamily have also been reported to have 
effects on angiogenesis that have been related to initiation and termination of placental neovascularization (Jackson et al. 1994), or to such pathological processes as diabetic retinopathy (Frystyk 2005).

In conclusion, we have demonstrated that S179D PRL is a potent anti-angiogenic factor in vivo. Part of the mechanism of action in endothelial cells is through decreased expression or release of a number of autocrine angiogenic factors, part is by interference with signaling from bFGF, and part is by disruption of cell migration, the latter most likely due to increased expression and release of inhibitors of matrix metalloproteases. S179D PRL is a molecular mimic of phosphorylated human PRL. The results therefore suggest that assessment is warranted of circulating phosphorylated PRL in conditions and disorders regulated by angiogenesis. Moreover, the results suggest that S179D PRL may be a useful anti-angiogenic therapeutic.

\section{Acknowledgements}

The authors thank Dr John Shyy for his critical reading of the manuscript.

\section{Funding}

This work was supported by NIH grant DK61005 to A MW and small research grant HD044783 to UO, and by a fellowship from $\mathrm{CNPq}$ (reference number 200719/2003-3) to E K M U. The authors declare that there is no conflict of interest that would prejudice the impartiality of this scientific work.

\section{References}

Baluk P, Hashizume H \& McDonald DM 2005 Cellular abnormalities of blood vessels as targets in cancer. Current Opinion in Genetics and Development 15 102-111.

Beck MT, Chen NY, Franek KJ \& Chen WY 2003 Prolactin antagonist-endostatin fusion protein as a targeted dualfunctional therapeutic agent for breast cancer. Cancer Research 63 3598-3604.

Ben-Jonathan N, Mershon JL, Allen DL \& Steinmetz RW 1996 Extrapituitary prolactin: distribution, regulation, functions, and clinical aspects. Endocrine Reviews 17 639-669.

Ben-Jonathan N, Liby K, McFarland M \& Zinger M 2002 Prolactin as an autocrine/paracrine growth factor in human cancer. Trends in Endocrinology and Metabolism 13 245-250.

Bergers G, Song S, Meyer-Morse N, Bergsland E \& Hanahan D 2003 Benefits of targeting both pericytes and endothelial cells in the tumor vasculature with kinase inhibitors. Journal of Clinical Investigation 111 1287-1295.
Bernichtein S, Kinet S, Jeay S, Llovera M, Madern D, Martial JA, Kelly PA \& Goffin V 2001 S179D-human PRL, a pseudophosphorylated human PRL analog, is an agonist and not antantagonist. Endocrinology 142 3950-3963.

Bustin SA 2000 Absolute quantification of mRNA using real-time reverse transcription polymerase chain reaction assays. Journal of Molecular Endocrinology 25 169-193.

Chen NY, Holle L, Li W, Peirce SK, Beck MT \& Chen WY 2002 In vivo studies of the anti-tumor effects of a human prolactin antagonist, hPRL-G129R. International Journal of Oncology 20 813-818.

Chen TJ, Kuo CB, Tsai KF, Liu JW, Chen DY \& Walker AM 1998 Development of recombinant human prolactin receptor antagonists by molecular mimicry of the phosphorylated hormone. Endocrinology 139 609-616.

Chun TH, Sabeh F, Ota I, Murphy H, McDonagh KT, Holmbeck K, Birkedal-Hansen H, Allen ED \& Weiss SJ 2004 MT1-MMP-dependent neovessel formation within the confines of the three-dimensional extracellular matrix. Journal of Cell Biology 167 757-767.

Clapp C \& Weiner RI 1992 A specific, high affinity, saturable binding site for the 16-kilodalton fragment of prolactin on capillary endothelial cells. Endocrinology 130 1380-1386.

Clapp C, Martial JA, Guzman RC, Rentier-Delure F \& Weiner RI 1993 The 16-kilodalton N-terminal fragment of human prolactin is a potent inhibitor of angiogenesis. Endocrinology 133 1292-1299.

Clapp C, Lopez-Gomez FJ, Nava G, Corbacho A, Torner L, Macotela Y, Duenas Z, Ochoa A, Noris G, Acosta E, Garay E \& Martinez de la Escalera G 1998 Expression of prolactin mRNA and of prolactin-like proteins in endothelial cells: evidence for autocrine effects. Journal of Endocrinology 158 137-144.

Clevenger CV \& Plank TL 1997 Prolactin as an autocrine/ paracrine factor in breast tissue. Journal of Mammary Gland Biology and Neoplasia 2 59-68.

Corbacho AM, Macotela Y, Nava G, Torner L, Duenas Z, Noris G, Morales MA, Martinez De La Escalera G \& Clapp C 2000 Human umbilical vein endothelial cells express multiple prolactin isoforms. Journal of Endocrinology 166 53-62.

Coss D, Kuo CB, Yang L, Ingleton P, Luben R \& Walker AM 1999 Dissociation of Janus kinase 2 and signal transducer and activator of transcription 5 activation after treatment of $\mathrm{Nb} 2$ cells with a molecular mimic of phosphorylated prolactin. Endocrinology 140 5087-5094.

Coss D, Yang L, Kuo CB, Xu X, Luben RA \& Walker AM 2000 Effects of prolactin on osteoblast alkaline phosphatase and bone formation in the developing rat. American Journal of Physiology. Endocrinology and Metabolism 279 E1216-E1225.

Costlow ME \& McGuire WL 1977 Autoradiographic localization of the binding of ${ }^{125}$ I-labelled prolactin to rat tissues in vitro. Journal of Endocrinology $\mathbf{7 5}$ 221-226. 
Duenas Z, Torner L, Corbacho AM, Ochoa A, GutierrezOspina G, Lopez-Barrera F, Barrios FA, Berger P, Martinez de la Escalera G \& Clapp C 1999

Inhibition of rat corneal angiogenesis by $16-\mathrm{kDa}$ prolactin and by endogenous prolactin-like molecules. Investigative Ophthalmology and Visual Science $\mathbf{4 0}$ 2498-2505.

Enge M, Bjarnegard M, Gerhardt H, Gustafsson E, Kalen M, Asker N, Hammes HP, Shani M, Fassler R \& Betsholtz C 2002 Endothelium-specific platelet-derived growth factor-B ablation mimics diabetic retinopathy. EMBO Journal 21 4307-4316.

Folkman J 1995 Angiogenesis in cancer, vascular, rheumatoid and other disease. Nature Medicine $127-31$.

Folkman J \& D'Amore PA 1996 Blood vessel formation: what is its molecular basis? Cell 87 1153-1155.

Frystyk J 2005 The growth hormone hypothesis - 2005 revision. Hormone and Metabolism Research 37 44-48.

Fuh G \& Wells JA 1995 Prolactin receptor antagonists that inhibit the growth of breast cancer cell lines. Journal of Biological Chemistry 270 13133-13137.

Goldhar AS, Vonderhaar BK, Trott JF \& Hovey RC 2005 Prolactin-induced expression of vascular endothelial growth factor via Egr-1. Molecular and Cellular Endocrinology 232 9-19.

Hata-Sugi N, Kawase-Kageyama R \& Wakabayashi T 2002 Characterization of rat aortic fragment within collagen gel as an angiogenesis model; capillary morphology may reflect the action mechanisms of angiogenesis inhibitors. Biological and Pharmaceutical Bulletin 25 446-451.

Hellstrom M, Gerhardt H, Kalen M, Li X, Eriksson U, Wolburg H \& Betsholtz C 2001 Lack of pericytes leads to endothelial hyperplasia and abnormal vascular morphogenesis. Journal of Cell Biology 153 543-553.

Hovey RC, Goldhar AS, Baffi J \& Vonderhaar BK 2001 Transcriptional regulation of vascular endothelial growth factor expression in epithelial and stromal cells during mouse mammary gland development. Molecular Endocrinology 15 819-830.

Hu ZZ, Meng J \& Dufau ML 2001 Isolation and characterization of two novel forms of the human prolactin receptor generated by alternative splicing of a newly identified exon 11. Journal of Biological Chemistry 276 41086-41094.

Huang KT, Chen YH \& Walker AM 2004 Inaccuracies in MTS assays: major distorting effects of medium, serum albumin, and fatty acids. Biotechniques 37 406, 408, 410-412.

Jackson D, Volpert OV, Bouck N \& Linzer DI 1994 Stimulation and inhibition of angiogenesis by placental proliferin and proliferin-related protein. Science $\mathbf{2 6 6}$ 1581-1584.

Kenyon BM, Voest EE, Chen CC, Flynn E, Folkman J \& D'Amato RJ 1996 A model of angiogenesis in the mouse cornea. Investigative Ophthalmology and Visual Science 37 1625-1632.
Kenyon BM, Browne F \& D’Amato RJ 1997 Effects of thalidomide and related metabolites in a mouse corneal model of neovascularization. Experimental Eye Research 64 971-978.

Khurana S, Kuns R \& Ben-Jonathan N 1999 Heparinbinding property of human prolactin: a novel aspect of prolactin biology. Endocrinology 140 1026-1029.

Kline JB, Rycyzyn MA \& Clevenger CV 2002 Characterization of a novel and functional human prolactin receptor isoform (delta S1PRLr) containing only one extracellular fibronectin-like domain. Molecular Endocrinology 16 2310-2322.

Kochendoerfer SK, Krishnan N, Buckley DJ \& Buckley AR 2003 Prolactin regulation of Bcl-2 family members: increased expression of bcl-xl but not mcl-1 or bad in Nb2-T cells. Journal of Endocrinology 178 265-273.

Krishna MM, Lin Y \& Englander SW 2004 Protein misfolding: optional barriers, misfolded intermediates, and pathway heterogeneity. Journal of Molecular Biology 343 1095-1109.

Krown KA, Wang YF, Ho TW, Kelly PA \& Walker AM 1992 Prolactin isoform 2 as an autocrine growth factor for GH3 cells. Endocrinology 131 595-602.

Kuo CB, Wu W, Xu X, Yang L, Chen C, Coss D, Birdsall B, Nasseri D \& Walker AM 2002 Pseudophosphorylated prolactin (S179D PRL) inhibits growth and promotes beta-casein gene expression in the rat mammary gland. Cell and Tissue Research 309 429-437.

Lessor T, Yoo JY, Davis M \& Hamburger AW 1998 Regulation of heregulin beta-1-induced differentiation in a human breast carcinoma cell line by the extracellular-regulated kinase (ERK) pathway. Journal of Cell Biochemistry 70 587-595.

Li QJ, Yao M, Wong W, Parpura V \& Martins-Green M 2004 The N- and C-terminal peptides of hIL8/CXCL8 are ligands for hCXCR1 and hCXCR2. FASEB Journal 18 776-778.

Lindahl P, Johansson BR, Leveen P \& Betsholtz C 1997 Pericyte loss and microaneurysm formation in PDGFB-deficient mice. Science 277 242-245.

Liu Y, Martindale JL, Gorospe M \& Holbrook NJ 1996 Regulation of p21 waf1/cip1 expression through mitogenactivated protein kinase signaling pathway. Cancer Research 56 31-35.

Llovera M, Pichard C, Bernichtein S, Jeay S, Touraine P, Kelly PA \& Goffin V 2000 Human prolactin (hPRL) antagonists inhibit hPRL-activated signaling pathways involved in breast cancer cell proliferation. Oncogene 19 4695-4705.

Lochnan HA, Buteau H, Richards S, Edery M \& Kelly PA 1995 Functional activity of the human prolactin receptor and its ligands. Molecular Cell Endocrinology 114 91-99.

Martins-Green M \& Kelly T 1998 The chicken chemotactic and angiogenic factor (9E3 gene product): its angiogenic properties reside in the $\mathrm{C}$-terminus of the molecule. Cytokine 10 819-830. 
Meister B, Jacobsson G \& Elde R 1992 Observations on the localization of prolactin receptor $\mathrm{mRNA}$ in rat tissues as revealed by in situ hybridization. Acta Physiologica Scandinavica 146 533-534.

Merkle CJ, Schuler LA, Schaeffer RC Jr, Gribbon JM \& Montgomery DW 2000 Structural and functional effects of high prolactin levels on injured endothelial cells: evidence for an endothelial prolactin receptor. Endocrine 13 37-46.

Naylor MJ, Oakes SR, Gardiner-Garden M, Harris J, Blazek K, Ho TW, Li FC, Wynick D, Walker AM \& Ormandy CJ 2005 Transcriptional changes underlying the secretory activation phase of mammary gland development. Molecular Endocrinology 19 1868-1883.

Ohta K \& Yachie A 2004 Development of vascular biology over the past 10 years: heme oxygenase- 1 in cardiovascular homeostasis. Journal of Endovascular Therapy 11 II140-II150.

Ozerdem U 2005 Targeting neovascular pericytes in neurofibromatosis type 1. Angiogenesis 7 307-311.

Ozerdem U \& Stallcup WB 2004 Pathological angiogenesis is reduced by targeting pericytes via the NG2 proteoglycan. Angiogenesis 7 269-276.

Perks CM, Keith AJ, Goodhew KL, Savage PB, Winters ZE \& Holly JM 2004 Prolactin acts as a potent survival factor for human breast cancer cell lines. British Journal of Cancer 91 305-311.

Pietras K \& Hanahan D 2004 A multitargeted, metronomic, and maximum-tolerated dose 'Chemo-Switch' regimen is antiangiogenic, producing objective responses and survival benefit in a mouse model of cancer. Journal of Clinical Oncology 23 939-952.

Royster M, Driscoll P, Kelly PA \& Freemark M 1995 The prolactin receptor in the fetal rat: cellular localization of messenger ribonucleic acid, immunoreactive protein, and ligand-binding activity and induction of expression in late gestation. Endocrinology 136 3892-3900.

Schroeder MD, Brockman JL, Walker AM \& Schuler LA 2003 Inhibition of prolactin (PRL)-induced proliferative signals in breast cancer cells by a molecular mimic of phosphorylated PRL, S179D-PRL. Endocrinology 144 5300-5307.

Struman I, Bentzien F, Lee H, Mainfroid V, D'Angelo G, Goffin V, Weiner RI \& Martial JA 1999 Opposing actions of intact and $\mathrm{N}$-terminal fragments of the human prolactin/growth hormone family members on angiogenesis: an efficient mechanism for the regulation of angiogenesis. PNAS 96 1246-1251.

Tan D, Johnson DA, Wu W, Zeng L, Chen YH, Chen WY, Vonderhaar BK \& Walker AM 2005 Unmodified prolactin (PRL) and S179D PRL-initiated bioluminescence resonance energy transfer between homo- and hetero-pairs of long and short human prolactin receptors in living human cells. Molecular Endocrinology 19 1291-1303.
Trott JF, Hovey RC, Koduri S \& Vonderhaar BK 2003 Alternative splicing to exon 11 of human prolactin receptor gene results in multiple isoforms including a secreted prolactin-binding protein. Journal of Molecular Endocrinology 30 31-47.

Tuazon PT, Lorenson MY, Walker AM \& Traugh JA 2002 p21-activated protein kinase gamma-PAK in pituitary secretory granules phosphorylates prolactin. FEBS Letters $\mathbf{5 1 5} 84-88$.

Wang HS, Hwang LL, Sue HF, Lee KM \& Chen CT 2004 A simple quantitative method for evaluation of angiogenesis activity. Assay and Drug Development Technologies 2 31-38.

Wang YF \& Walker AM 1993 Dephosphorylation of standard prolactin produces a more biologically active molecule: evidence for antagonism between nonphosphorylated and phosphorylated prolactin in the stimulation of $\mathrm{Nb} 2$ cell proliferation. Endocrinology 133 2156-2160.

Wang YF, Liu JW, Mamidi M \& Walker AM 1996 Identification of the major site of rat prolactin phosphorylation as serine 177. Journal of Biologial Chemistry $2712462-2469$.

Wu W, Coss D, Lorenson MY, Kuo CB, Xu X \& Walker AM 2003 Different biological effects of unmodified prolactin and a molecular mimic of phosphorylated prolactin involve different signaling pathways. Biochemistry 42 7561-7570.

Wu W, Ginsburg E, Vonderhaar BK \& Walker AM 2005 $\mathrm{S} 179 \mathrm{D}$ prolactin increases vitamin $\mathrm{D}$ receptor and $\mathrm{p} 21$ through upregulation of short $1 \mathrm{~b}$ prolactin receptor in human prostate cancer cells. Cancer Research $\mathbf{6 5}$ 7509-7515.

Xu X, Kreye E, Kuo CB \& Walker AM 2001 A molecular mimic of phosphorylated prolactin markedly reduced tumor incidence and size when DU145 human prostate cancer cells were grown in nude mice. Cancer Research $\mathbf{6 1}$ 6098-6104.

Xu X, Wu W, Williams V, Khong A, Chen YH, Deng C \& Walker AM 2003 Opposite effects of unmodified prolactin and a molecular mimic of phosphorylated prolactin on morphology and the expression of prostate specific genes in the normal rat prostate. Prostate 54 25-33.

Yang L, Kuo CB, Liu Y, Coss D, Xu X, Chen C, Oster-Granite ML \& Walker AM 2001 Administration of unmodified prolactin (U-PRL) and a molecular mimic of phosphorylated prolactin (PP-PRL) during rat pregnancy provides evidence that the U-PRL:PP-PRL ratio is crucial to the normal development of pup tissues. Journal of Endocrinology 168 227-238.

Yang L, Lii S, Kuo B, Buckley A, Buckley D, Chen C, Xu X, Coss D \& Walker AM 2002 Maternal prolactin composition can permanently affect epidermal gammadeltaT cell function in the offspring. Developmental and Comparative Immunology $\mathbf{2 6}$ 849-860. 
